\title{
Dynamics of the status of groundwater in the Polish Lowland: the River Gwda catchment example
}

\author{
Izabela Jamorska*, Katarzyna Kubiak-Wójcicka, Arkadiusz Krawiec \\ Faculty of Earth Sciences, Nicolaus Copernicus University in Toruń, Lwowska 1, 87-100 Toruń, Poland \\ *corresponding author, e-mail: izabela.jamorska@umk.pl
}

\begin{abstract}
The aim of the present study is to monitor changes in the location of the groundwater table in the catchment area of the River Gwda within the Quaternary and Neogene water-bearing level over a 35-year period, between 1981 and 2015. In addition, on account of very diverse total annual precipitation levels in particular parts of the catchment, attempts were made to determine the influence of precipitation on the location of the groundwater table. By correlating groundwater level and meteorological parameters (precipitation), it was discovered that precipitation in the previous year made the largest impact on the groundwater table. Moreover, low precipitation totals in the southern part of the catchment are not discernible in groundwater table fluctuations, which is linked to the location of the observation well within the drainage zone as well as to water ascension from deeper aquifers.
\end{abstract}

Key words: groundwater table, precipitation, River Gwda catchment, hydrogeology

\section{Introduction}

The main source of groundwater recharge is precipitation and its temporal distribution, which, in turn, impact the rhythm of groundwater table fluctuations (Chełmicki, 1991). Renewability of groundwater resources is also connected to the geological structure of an area. Depending on conditions of natural occurrence and links to the hydrographic network, groundwater creates local or regional water circulation systems (Toth, 1963; Szymanko, 1980). A significant problem is connected with the identification of shallow groundwater circulation systems (so-called local systems), which participate in supplying river systems, maintaining their permanence, especially during periods of drought and which have an impact on the pace and level of the renewability of deep groundwater resources (Graf, 2008). The recognition of links between precipita- tion and groundwater levels has great significance for quantitative conservation, sustainable management and more targeted exploitation in future (Dobek, 2007). The location of the groundwater aquifer is essential from an economic point of view: water supply, response time and renewability of groundwater resources.

Assessments of groundwater table dynamics were conducted for different regions across Poland in the past (Zdralewicz \& Lejcuś, 2008; Mostowik et al., 2018). However, the greatest interest revolved around those areas with water deficiencies such as Great Poland (Graf, 2008; Grajewski et al., 2014) and Kuyavia (Przybyłek \& Nowak, 2011; Jamorska, 2015) as well as large agglomerations where there is a considerable water demand (Jokiel \& Moniewski, 2000; Worsa-Kozak et al., 2008; Tomalski, 2011; Bartnik \& Tomalski, 2012; Jędruszkiewicz et al., 2016). 


\section{Research area}

The study area includes the catchment of the River Gwda (Fig. 1), which is a fourth-order tributary that connects with the River Noteć and has a total length of $139.95 \mathrm{~km}$, whereas its catchment area attains 4,947.27 $\mathrm{km}^{2}$ (APHP, 2005). It is a lakeland catchment, with numerous blind drainage depressions and considerable participation of lakes and forests. The forest area (woodland index) constitutes 30 per cent of the total area, while that of lakes (lake density index) does not exceed 2.5 per cent (Kubiak-Wójcicka \& Lewandowska, 2014). Agricultural farmland constitutes 44.4 per cent of the entire catchment area of the River Gwda (Kubiak-Wójcicka \& Kornaś, 2015). According to the physico-geographical division of Poland by Kondracki (2002), the study area belongs to the following mesoregions: the valley of the River Gwda, the Drawsko Lake District, the Szczecinek Lakeland, the Wałcz Plain, the Wałcz Lake District, the Krajna Lake land and the Charzykowy Plain.
The catchment area is morphologically diverse, representing remnants of the Vistulian glaciation. The emergence of geomorphological forms indicates that these formed under conditions of areal deglaciation, conditioned by post-glacial land morphology (Mojski, 2005). In the geological structure of Pleistocene strata special attention should be paid to the presence of numerous buried valleys and tunnel valley structures. Pleistocene deposits occur most of the surface area of the River Gwda catchment (Fig. 2), with the exception of small areas in the southern part, where small Neogene sediment xenoliths were identified (Bartczak, 2009).

On average, the thickness of Pleistocene deposits varies between 70 and $150 \mathrm{~m}$; in sub-glacial tunnel valleys and glaciotectonic depressions it may exceed 180 m (Dobracka, 2005; Popielski, 2005). In the wells penetrating Pleistocene strata, deposits of the Elster and Warthanian glaciations prevail, forming a complex consisting of strata formed during several, most commonly three, glacial series (Bartczak, 2009). These series are represented

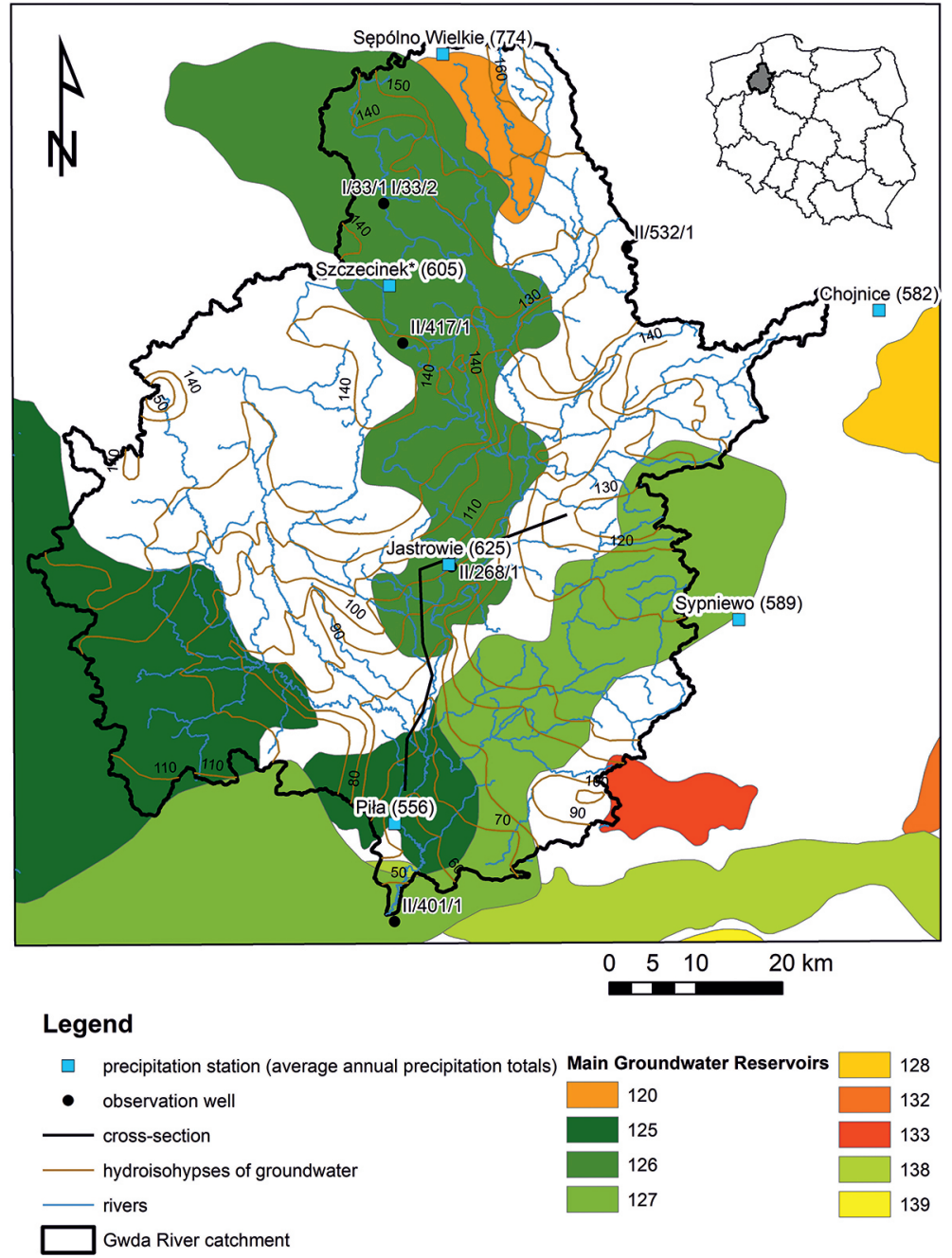

Fig. 1. The catchment area of the River Gwda 


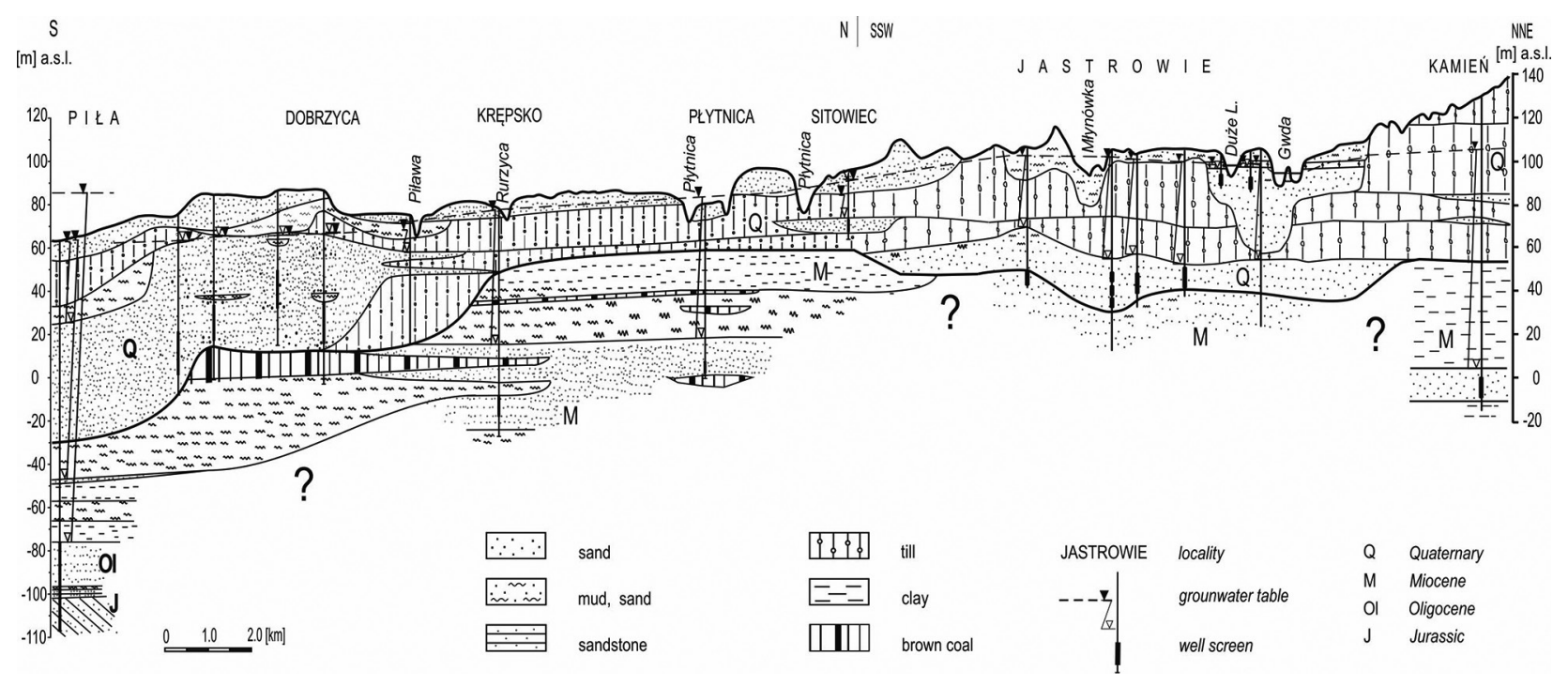

Fig. 2. Hydrogeological cross section

by tills along with fluvioglacial and marginal water-logged deposits, which separate till levels and which are genetically connected. Strata formed during the Vistulian glaciation are represented by two separate glacial levels formed during the Leszno and Poznań, as well as the Pomeranian glaciation phase. They consist of deposits of two glacial series, mainly glacial till separated by water-logged and fluvioglacial strata of varying thicknesses. Deposits of the Pomeranian glaciation phase are represented mainly by fluvioglacial sands and gravels that form extensive outwash covers and, locally, water-logged strata. The Pleistocene/Holocene transition is connected with the formation of numerous dunes and aeolian sand zones.

\section{Material and methods}

In the present study, data on precipitation levels from seven meteorological stations of the Institute of Meteorology and Water Management - National Research Institute (IMGW-PIB), as well as data on the status of groundwater in six observational wells of the Polish Geological Institute - National Re- search Institute (PIG-PIB) have been used. This joint research covers the period between 1981 and 2015.

On the basis of daily precipitation totals, average monthly, annual and multi-annual precipitation total values have been calculated. Of seven meteorological stations, four are located in the catchment area of the River Gwda (Sępólno Wielkie, Szczecinek, Jastrowie and Piła), whereas the remaining three (Sypniewo, Wierzchowo and Chojnice) are situated in the immediate proximity to this catchment. Meteorological conditions in the upper River Gwda catchment reflect data presented for the meteorological stations at Sępólno Wielkie, Szczecinek and Chojnice; in the central part of the River Gwda drainage basin they are data obtained at stations located Sypniewo, Jastrowie and Wierzchowo, whereas meteorological conditions in the southern part of the catchment area are identical to those presented for the meteorological station at Piła. For the precipitation station at Szczecinek, data refer to the period between 1981 and 2009.

Monitoring of the status of groundwater in observation wells and boreholes is conducted on a regular basis every seven days (Table 1 ). The majority of observation wells represent the Quaternary wa-

Table 1. Characteristics of the observation points

\begin{tabular}{|c|c|c|c|c|c|c|c|}
\hline $\begin{array}{c}\text { Well } \\
\text { number }\end{array}$ & Location (voivodeship) & $\begin{array}{l}\text { Aquifer } \\
\text { age }\end{array}$ & $\begin{array}{l}\text { Elevation } \\
\text { (m a.s.l.) }\end{array}$ & $\begin{array}{l}\text { Water } \\
\text { table type }\end{array}$ & Lithology & $\begin{array}{l}\text { Borehole } \\
\text { depth }(\mathrm{m})\end{array}$ & $\begin{array}{l}\text { Groundwater table } \\
\text { elevation ( } \mathrm{m} \text { a.s.l.) }\end{array}$ \\
\hline $\mathrm{I} / 33 / 1$ & Spore (West Pomerania) & $\mathrm{Ng} / \mathrm{M}$ & 138.63 & perched & sands & 197.0 & 137.86 \\
\hline $\mathrm{I} / 33 / 2$ & Spore (West Pomerania) & Q & 138.80 & perched & $\begin{array}{c}\text { gravels and } \\
\text { sands }\end{array}$ & 42.0 & 137.60 \\
\hline II/268/1 & Jastrowie (Greater Poland) & Q & 105.56 & perched & sands & 48.5 & 101.86 \\
\hline II/401/1 & Ujście (Greater Poland) & Q & 62.21 & free & sands & 30.0 & 49.20 \\
\hline II $/ 417 / 1$ & Turowo (West Pomerania) & Q & 158.96 & free & sands & 24.0 & 153.00 \\
\hline II/532/1 & Rzeczenica (Pomerania) & Q & 150.00 & perched & sands & 22.8 & 144.50 \\
\hline
\end{tabular}


ter-bearing level, including perched water table ( 3 piezometers) and free water table (2 piezometers). Observation well number I/33/1, which monitors the groundwater status of the Neogene aquifer, is located in the northern part of the catchment, between the lakes of Wierzchowo and Wielimie.

On the basis of the data presented above, the average monthly, annual and multi-annual water status in particular boreholes have been calculated. The adopted joint 35-year observation period suffices to determine the variability of the status of groundwater in conjunction to precipitation levels. Based on suggestions made by Kundzewicz \& Robson (2004), only a long monitoring data record and a suitable location of the observation station will provide appropriate documentation for the identification of hydrological changes. The location of meteorological stations and observation wells is illustrated in Figure 1.

Assessments of the status of the groundwater table in relationship to natural conditions have been carried out by means of the normalisation coefficient $k$ (Hołownia \& Wierzbicka, 1996), which takes the following form:

$$
k=1-\left(\frac{h_{i}}{S S W}\right)
$$

where $h_{i}$ is current (for a specific year) groundwater table status and SSW is the mean multi-annual groundwater table status.

The normalisation coefficient can take positive and negative values. Positive values indicate that the current status of the groundwater table is higher than the mean multi-annual one, while negative values show that the current status is lower than the mean multi-annual one. The calculated values of the coefficient allow to determine whether a given year was drier or wetter than usual.

The strength of the connection between annual precipitation totals and groundwater level has been determined on the basis of the correlation and dependence coefficient $r$. The higher the value of the correlation and dependence coefficient $r$, the higher the dependence of the groundwater status on precipitation levels. On account of the depth of the groundwater table and the precipitation time reaction, the transfer of reactions in groundwater status to precipitation levels has been analysed $(r+1, r+2)$.

\section{Hydrogeology of the area}

Groundwater in the River Gwda catchment occurs in Quaternary, Neogene, Paleogene and Jurassic formations. The largest range and significance in water supply for human consumption is seen in the Quaternary aquifer of uneven recognition. The main usable water-bearing level is most frequently located at a depth between 30 and 50 metres in intermoraine layers. The whole catchment area of the River Gwda belongs to Groundwater Body number 26 , which has a pore structure and where aquifers consist of sands, the permeability coefficient of which ranges from $10^{-4}$ to $10^{-6} \mathrm{~m} / \mathrm{s}$.

Within the boundaries of the River Gwda catchment six Main Groundwater Reservoirs are located,

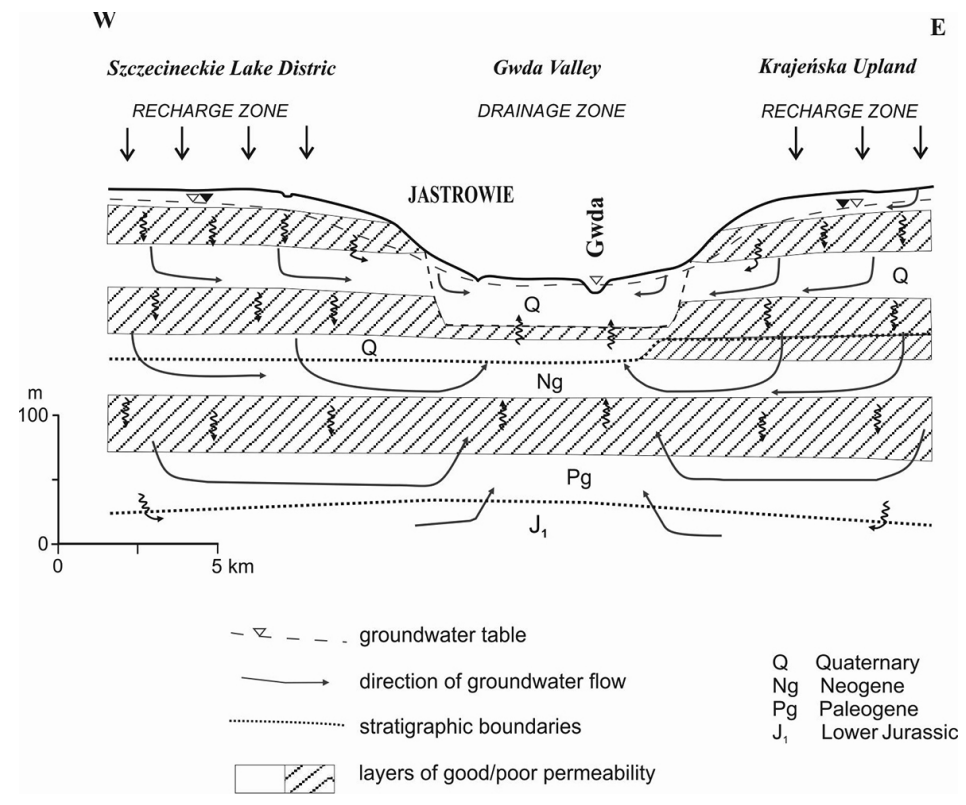

Fig. 3. Schematic diagram of groundwater circulation (Krawiec et al., 2005) 
either partially or entirely (Fig. 1). The largest area is occupied by the Main Groundwater Reservoir Szczecinek, which is situated in the northern and central part of the catchment and the sub-reservoir Złotów-Piła-Strzelce Krajeńskie occupying the southern and eastern part of the catchment area. There is only one Main Groundwater Reservoir, which is located in its entirety within the boundaries of the catchment area, i.e., the Intermoraine Reservoir Bobolice.

The groundwater aquifer occurs within structures of sandy and gravelly river valleys, outwash plains, eskers, kames and terminal moraines that date back to the last glaciation at varying depths, most commonly within valleys in the range from 0.5 to 3.0 metres; in uplands this is between 3.0 and 20.0 metres. In areas of terminal moraines this aquifer often occurs in "suspended" form, not constituting a usable water-bearing level (Dąbrowski et al., 2013). The recharge of water-bearing layers of the subsurface aquifer occurs as a result of direct infiltration of precipitation. Deeper aquifers are indirectly supplied by means of water seepage through poorly permeable sediments (Fig. 3).

The River Gwda constitutes the water drainage base; however, groundwater run-off occurs to the southwest into the valleys of the rivers Noteć and Warta. The usable Neogene aquifers occur mainly in fine- and medium-grained sands of Miocene age, and in the valley of the River Gwda they acquire an artesian nature (Krawiec et al., 2005).

\section{Findings and discussion}

\subsection{Precipitation}

The spatial distribution of annual precipitation totals depends on the location of particular meteorological stations. Meteorological conditions in the upper part of the catchment area of the River Gwda and its immediate vicinity present data from three precipitation stations: Sępólno Wielkie, Szczecinek and Chojnice. The highest rainfall totals in this part of the catchment area were recorded at Sepólno Wielkie, where mean multi-annual values reached $774 \mathrm{~mm}$ between 1983 and 2015 (Table 2). At the other meteorological stations average annual precipitation totals were considerably lower and ranged from 581.8 $\mathrm{mm}$ at Chojnice to $604.7 \mathrm{~mm}$ at Szczecinek.

The meteorological stations at Wierzchowo, Jastrowie and Sypniewo were used to determine the level of precipitation in the central part of the River Gwda catchment. The annual precipitation total in the period between 1981 and 2015 in this part of the catchment ranges from $882 \mathrm{~mm}$ at Wierzchowo to $624.9 \mathrm{~mm}$ at Jastrowie. In the lower part of the River Gwda catchment, average annual precipitation totals in the multi-annual period are the lowest and amount to $556.2 \mathrm{~mm}$ at the Piła meteorological station. The highest annual precipitation total values were recorded in 2007 (809.6 mm), the lowest in 2003 (428.3 mm). Taking the average value, it can be concluded that the annual precipitation total from all seven meteorological stations located within the River Gwda catchment area did not exceed 630 $\mathrm{mm}$. In the period studied, wet summers occurred in 1998, 2007, 2010 and 2012, dry summers in 1982, 1989, 1992, 2003 and 2015 (Fig. 4). During wet years, annual precipitation totals exceeded the value of $750 \mathrm{~mm}$, which means that they were higher by 19 to 30 per cent than the average multi-annual values. However, during dry years, annual precipitation totals were lower than average multi-annual values by as much as approximately 40 per cent.

Analyses conducted showed that average precipitation totals recorded in the River Gwda catchment area overlapped with generally accepted wet and dry years for the territory of Poland within the multi-annual period under study. For example, the year 2010 is considered to have been par-

Table 2. Average, maximum and minimum annual precipitation totals recorded at meteorological stations between 1981 and 2015

\begin{tabular}{lccc}
\hline $\begin{array}{c}\text { Precipitation } \\
\text { station }\end{array}$ & $\begin{array}{c}\text { Average annual precipitation } \\
\text { totals I-XII (mm) }\end{array}$ & $\begin{array}{c}\text { Maximum annual precipitation } \\
\text { totals (year) (mm) }\end{array}$ & $\begin{array}{c}\text { Minimum annual precipitation } \\
\text { totals (year) }(\mathrm{mm})\end{array}$ \\
\hline Chojnice & 581.8 & $834.5(2007)$ & $311.8(1982)$ \\
Jastrowie & 624.9 & $864.2(2007)$ & $375.6(1982)$ \\
Piła & 556.2 & $778.1(2012)$ & $302.4(2015)$ \\
Sępolno Wielkie* & 774.1 & $1054.9(2007)$ & $581.8(2003)$ \\
Sypniewo & 588.9 & $858.8(2010)$ & $316.8(2015)$ \\
Szczecinek* & 604.7 & $855.0(1998)$ & $339.2(2000)$ \\
Wierzchowo & 684.7 & $882.0(2010)$ & $376.1(1982)$ \\
\hline
\end{tabular}

* - records for the period 1983-2015.

** - records for the period 1981-2009. 


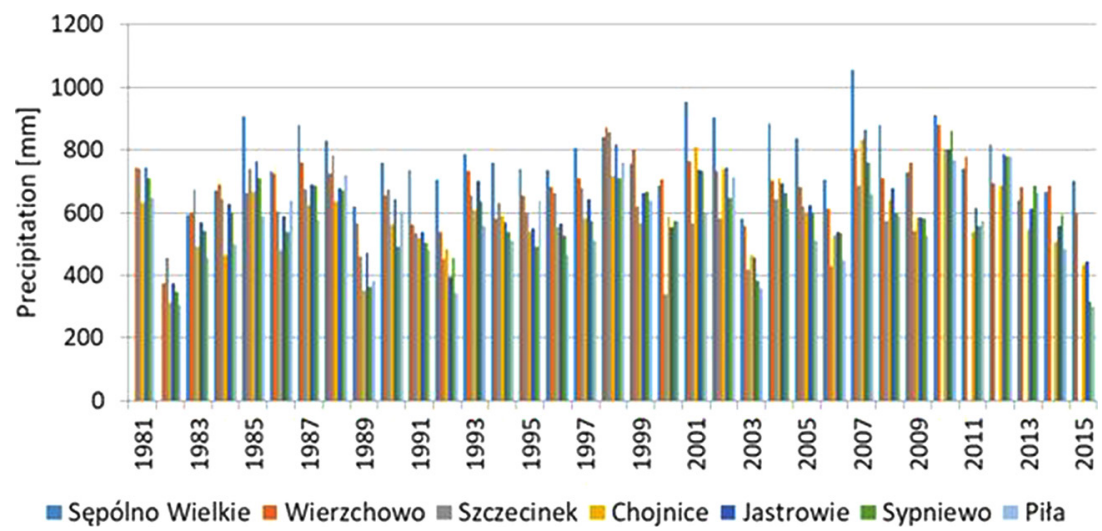

Fig. 4. Annual precipitation totals (mm) for selected meteorological stations in the period between 1981 and 2015

ticularly wet in the River Vistula catchment area, which is connected with the occurrence of precipitation floods in the entire river basin. At the time, the maximum precipitation totals were recorded at most meteorological stations in the upper and central parts of the River Vistula basin when the entire multi-annual period from 1951 to 2015 is taken into consideration (Kubiak-Wójcicka, 2019). However, it must be emphasised that, when we analyse precipitation totals at particular meteorological stations within the River Gwda catchment separately, the years 2007 and 2012 turn out to have been the most humid, as shown by records from the meteorological stations at Sępólno Wielkie, Chojnice and Jastrowie for the year 2007 and the Piła staion for the year 2012. In contrast, the lowest precipitation totals were recorded at the Wierzchowo, Chojnice and Jastrowie stations in 1982 and at Piła and Sypniewo in 2015. These findings indicate that precipitation conditions which can be found within the River Gwda catchment area are diversified both in terms of amount of rainfall and spatial distribution.

\subsection{Groundwater status}

Analyses of the average weekly, monthly and annual groundwater status indicate that the level of the groundwater table within the multi-annual period under study was similar in all piezometers. The greatest fluctuations were recorded in the observation well number II/532/1, situated in the northeastern part of the catchment (Fig. 5), where the water table is perched. In spite of high fluctuation amplitudes, the overall shape of the water table level curve in this piezometer provides evidence of similar groundwater reactions to those observed in the remaining observation wells.

Figure 5 clearly shows that, despite the intake of aquifers from different time periods and depths, the water table in the observation wells numbers I/33/1 and I/33/2 is closely similar: well I/33/1, at a depth of $197 \mathrm{~m}$ records data from the Neogene water-bearing layer, whereas well I/33/2, which reaches only $42 \mathrm{~m}$ in depth, records data from the Quaternary aquifer. The detailed course of water table fluctuations from these monitoring points is illustrated in Figure 6.

This situation may be indicative of the presence of hydrogeological windows between particular aquifers. In addition, average annual amplitude for observation well number I/33/1, which extracts water from the Neogene water-bearing layer, and for well I/33/2, extracting water from the Quaternary aquifer, is virtually identical and amounts to $0.27 \mathrm{~m}$, whereas the multi-annual amplitude is at the $0.8-\mathrm{m}$ level. This situation is confirmed by data published by Kotowski \& Najman (2015), who conducted research in the same area. Their results showed the occurrence of a strong hydraulic connection between aquifers and also indicated a great significance of deeply indented river and lake valleys, deep erosion tunnel valleys and buried valleys for the groundwater circulation system as these forms considerably facilitate water seepage to deeper water-bearing levels.

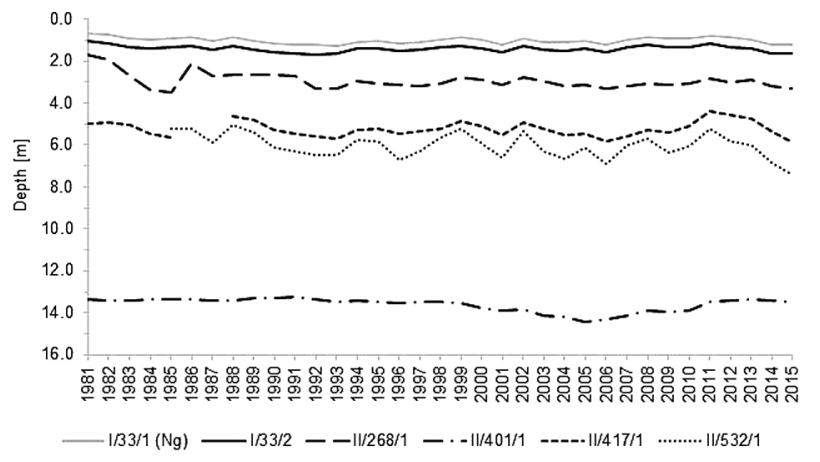

Fig. 5. Groundwater status in selected observation wells 


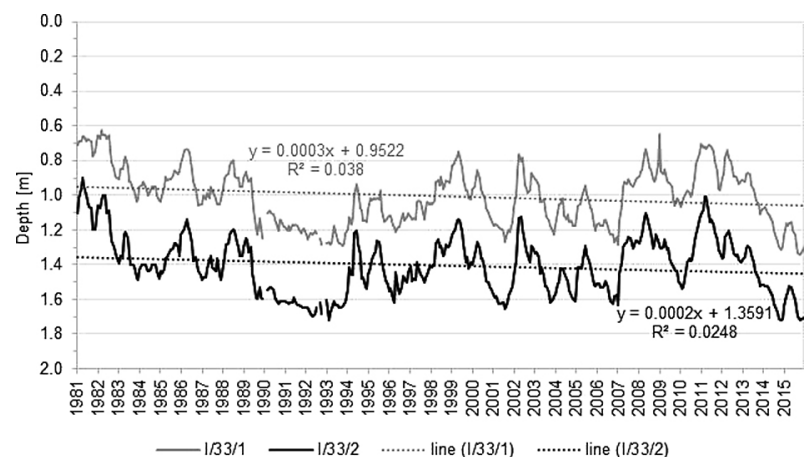

Fig. 6. Groundwater status in the Neogene (I/33/1) and Quaternary aquifers (I/33/2) within the multi-annual period under study

The multi-annual amplitude of water table fluctuations for the remaining piezometers that extract from the Quaternary aquifer, ranged from $2.12 \mathrm{~m}$ for observation well II/417/1 to $3.99 \mathrm{~m}$ for the shallowest observation well II/532/1 (at a depth $22.8 \mathrm{~m}$ ) (Table 3). The ratio of annual amplitude to multi-annual amplitude allows us to conclude that, along with the increase of the depth of the observed aquifer, the prevalence of multi-annual fluctuations over seasonal fluctuations is more prominently marked.

Further on in the present study, the normalisation coefficient $k$, which determines the level of the groundwater table in relation to natural conditions, has been identified. In order to calculate the normalisation coefficient in the River Gwda catchment, four boreholes have been selected, each located in different parts of the catchment area: in the north (observation well II/33/2), centre (wells II/417/1 andII/268/1) and south (well II/401/1) (Table 4). Among the piezometers selected, two represent a free water table (II/401/1, II/417/1), the other two a perched water table.

On the basis of results obtained from three observation wells (II/417/1, I/33/2 and II/268/1) it can be concluded that the level of the groundwater table, which was higher than the multi-annual average, irrespective of depth or location of the boreholes, occurred in the years 1981-1983, 1986, 1988, 1999, 2011 and 2013. A lower groundwater status was recorded in the years 2001 and 2004-2006. A groundwater status that is lower than the multi-annual average is particularly noticeable in the first decade of the new millennium, which is also confirmed by the trend line marked out for the piezometers under study (Figs 7-9).

Table 4. Normalisation coefficient $k$

\begin{tabular}{|c|c|c|c|c|}
\hline Year & $\mathrm{I} / 33 / 2$ & II/268/1 & II/401/1 & II $/ 417 / 1$ \\
\hline 1981 & 0.251 & 0.425 & 0.020 & 0.047 \\
\hline 1982 & 0.181 & 0.338 & 0.012 & 0.061 \\
\hline 1983 & 0.035 & 0.084 & 0.012 & 0.042 \\
\hline 1984 & -0.010 & -0.157 & 0.019 & -0.042 \\
\hline 1985 & 0.040 & -0.188 & 0.019 & -0.073 \\
\hline 1986 & 0.084 & 0.283 & 0.020 & - \\
\hline 1987 & -0.018 & 0.084 & 0.013 & - \\
\hline 1988 & 0.085 & 0.088 & 0.015 & 0.115 \\
\hline 1989 & -0.025 & 0.094 & 0.025 & 0.083 \\
\hline 1990 & -0.124 & 0.092 & 0.023 & -0.014 \\
\hline 1991 & -0.156 & 0.081 & 0.027 & -0.041 \\
\hline 1992 & -0.185 & -0.132 & 0.019 & -0.068 \\
\hline 1993 & -0.169 & -0.126 & 0.008 & -0.094 \\
\hline 1994 & -0.004 & -0.002 & 0.016 & -0.014 \\
\hline 1995 & 0.016 & -0.040 & 0.008 & 0.005 \\
\hline 1996 & -0.084 & -0.070 & 0.006 & -0.048 \\
\hline 1997 & -0.036 & -0.097 & 0.009 & -0.020 \\
\hline 1998 & 0.058 & -0.053 & 0.011 & -0.002 \\
\hline 1999 & 0.104 & 0.049 & 0.005 & 0.075 \\
\hline 2000 & 0.001 & 0.013 & -0.013 & 0.023 \\
\hline 2001 & -0.136 & -0.067 & -0.020 & -0.054 \\
\hline 2002 & 0.084 & 0.064 & -0.019 & 0.057 \\
\hline 2003 & -0.053 & -0.008 & -0.038 & 0.004 \\
\hline 2004 & -0.078 & -0.086 & -0.043 & -0.050 \\
\hline 2005 & -0.010 & -0.077 & -0.060 & -0.045 \\
\hline 2006 & -0.104 & -0.132 & -0.054 & -0.113 \\
\hline 2007 & 0.055 & -0.085 & -0.040 & -0.067 \\
\hline 2008 & 0.135 & -0.055 & -0.022 & -0.004 \\
\hline 2009 & 0.033 & -0.063 & -0.025 & -0.034 \\
\hline 2010 & 0.032 & -0.044 & -0.019 & 0.022 \\
\hline 2011 & - & 0.030 & 0.011 & 0.164 \\
\hline 2012 & - & -0.036 & 0.015 & 0.133 \\
\hline 2013 & - & 0.005 & 0.020 & 0.093 \\
\hline 2014 & - & -0.081 & 0.014 & -0.018 \\
\hline 2015 & - & -0.130 & 0.009 & -0.121 \\
\hline
\end{tabular}

Table 3. Selected statistical parameters of groundwater table fluctuations within the multi-annual period

\begin{tabular}{lcccccc}
$\begin{array}{c}\text { Well } \\
\text { number }\end{array}$ & $\begin{array}{c}\text { Multiannual } \\
\text { maximum }(\mathrm{m})\end{array}$ & $\begin{array}{c}\text { Multiannual } \\
\text { minimum }(\mathrm{m})\end{array}$ & $\begin{array}{c}\text { Average } \\
(\mathrm{m})\end{array}$ & $\begin{array}{c}\text { Average annual } \\
\text { amplitude }(\mathrm{m})\end{array}$ & $\begin{array}{c}\text { Multiannual } \\
\text { amplitude }(\mathrm{m})\end{array}$ & $\begin{array}{c}\text { Ratio of annual amplitude } \\
\text { to multiannual amplitude }\end{array}$ \\
\hline $\mathrm{I} / 33 / 1$ & 0.70 & 1.26 & 1.01 & 0.27 & 0.85 & 0.32 \\
$\mathrm{I} / 33 / 2$ & 1.05 & 1.67 & 1.41 & 0.27 & 0.79 & 0.34 \\
$\mathrm{II} / 268 / 1$ & 1.69 & 3.48 & 2.93 & 0.37 & 2.30 & 0.16 \\
$\mathrm{II} / 401 / 1$ & 13.23 & 14.42 & 13.61 & 0.59 & 2.30 & 0.26 \\
$\mathrm{II} / 417 / 1$ & 4.38 & 5.87 & 5.24 & 0.58 & 2.12 & 0.27 \\
$\mathrm{II} / 532 / 1$ & 5.04 & 7.46 & 6.04 & 1.16 & 3.99 & 0.29 \\
\hline
\end{tabular}




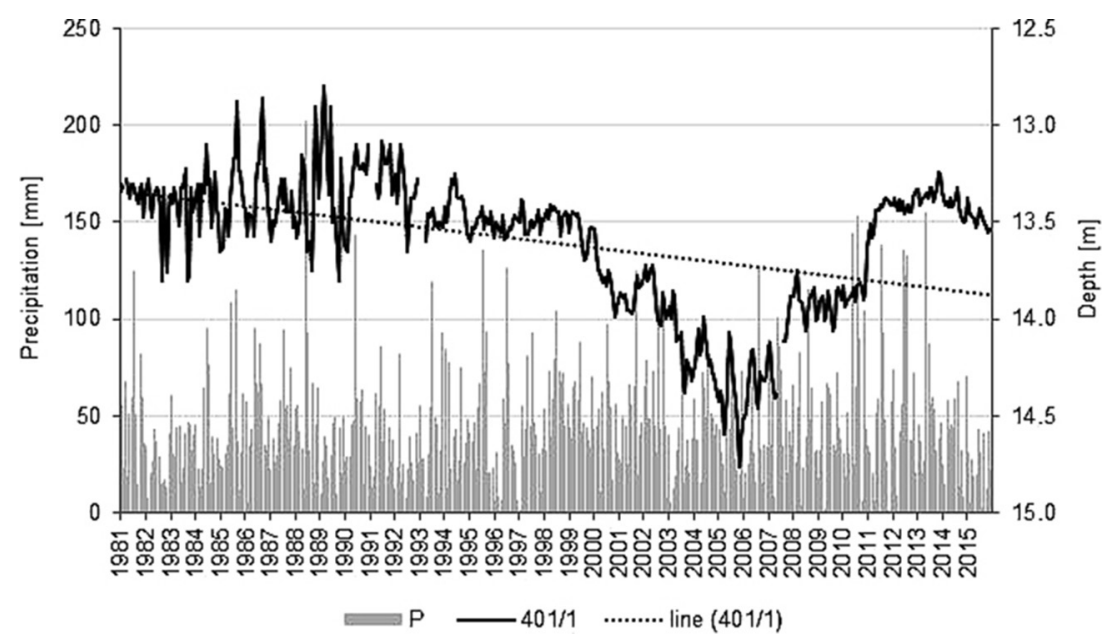

Fig. 7. Average monthly groundwater status from piezometer II/401/1 in relation to average monthly precipitation totals $(P)$ from the Piła meteorological station

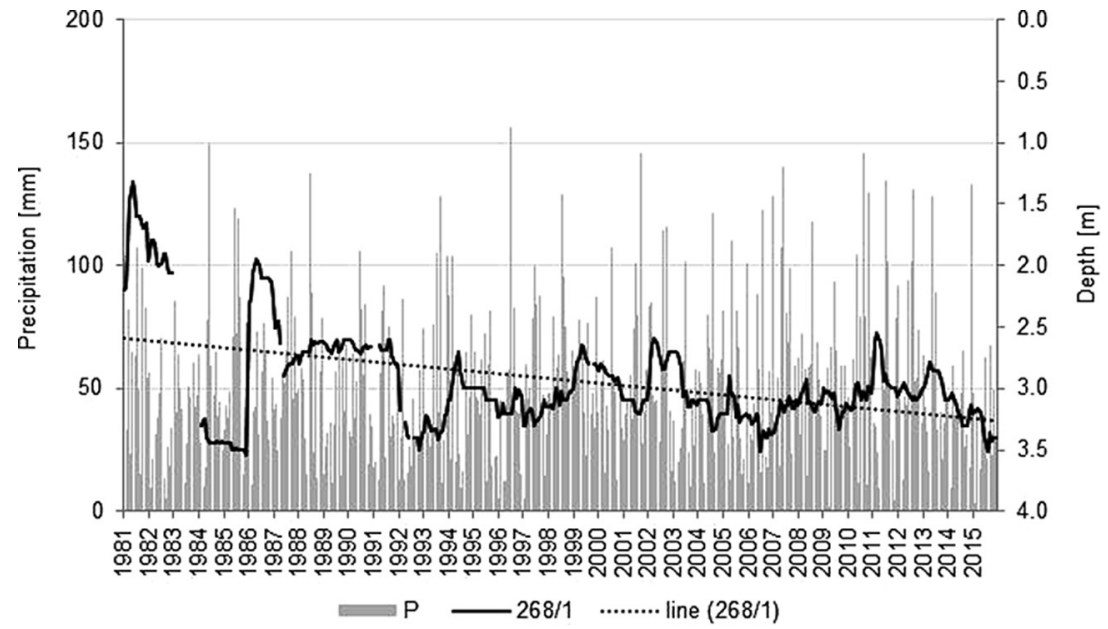

Fig. 8. Average monthly groundwater status from piezometer II/268/1 in relation to average monthly precipitation totals $(P)$ from the Jastrowie meteorological station

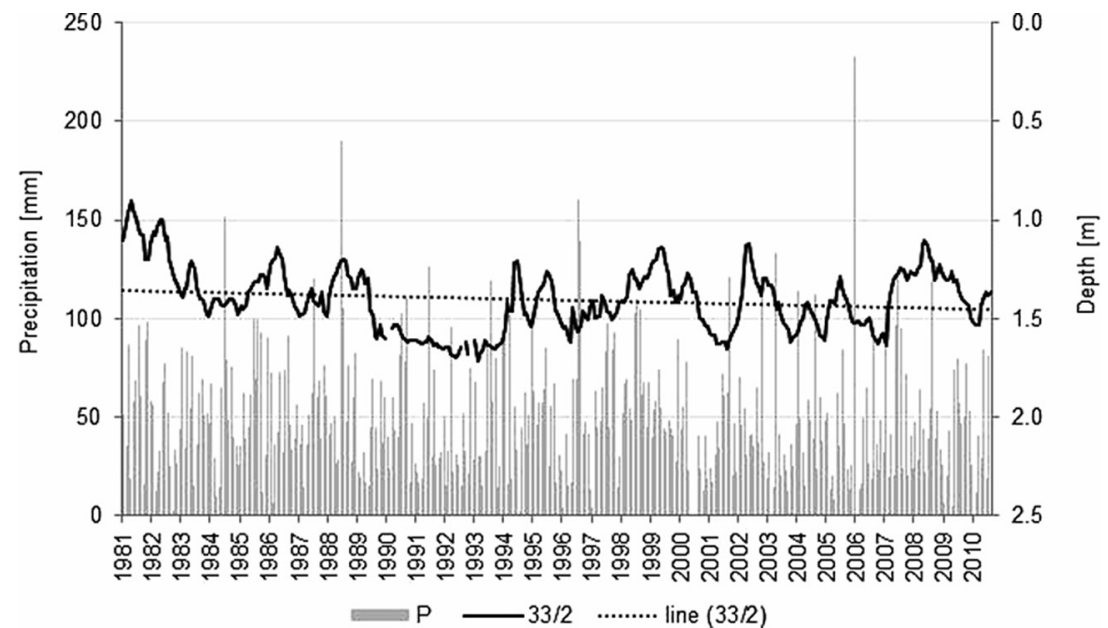

Fig. 9. Average monthly groundwater status from piezometer I/33/2 in relation to average monthly precipitation totals (P) from the Szczecinek meteorological station 
The situation in the observation well II/401/1 looks completely different since the positive and negative values of the naturalisation coefficient $k$ do not occur alternately every several years, but represent much longer time intervals (Table 4). Moreover, following an analysis of the variability of the groundwater table depth in this observation well, no considerable influence of precipitation could be identified, despite the free water table. This borehole, the depth of which does not exceed 30 metres, is situated in the immediate vicinity of the River Gwda catchment, in a valley landscape, i.e., the Torun-Eberswald marginal stream valley. The location of the observation well in the drainage area causes that the aquifer, the thickness of which exceeds 30 metres, is recharged mainly by the inflow of water from interclay water-bearing layers as well as by ascension of water from deeper aquifers. Consequently, low precipitation totals typical of this region (approximately $550 \mathrm{~mm}$, on average), comparable with evaporation, are not discernible in the reaction of the well's groundwater table (II/401/1).

\subsection{The relationship between precipitation and groundwater status}

In order to conduct a detailed analysis of the dependence between precipitation levels and groundwater status, an assessment concerning the influence of precipitation levels recorded at the meteorological station located closest to the piezometer in the four selected observation wells was conducted (Figs 7-9) and the correlation coefficient was calculated (Table 5). This measure was taken in view of the wide variations in precipitation levels in particular parts of the catchment, which range from $556.2 \mathrm{~mm}$ at Piła to $774.1 \mathrm{~mm}$ recorded at Sępólno Wielkie.

The correlation coefficient attains the highest values between precipitation in a given year and groundwater status the following year. Such a situation occurs irrespective of the water table type and its depth, with the exception of correlation coefficient result from observation well II/401/1, where calculations performed did not reveal any correlation between precipitation and water table levels either within one-year or two-year periods. These findings are also confirmed by plots presenting the relationship between average monthly groundwater status and average monthly precipitation totals.

Comparing the results obtained for groundwater with those relating to precipitation, we can conclude that the increase in the water table level usually occurs after a wet year, whereas a groundwater status lower than the multi-annual average can even last for several years after rain-free periods (Figs 7-9).

The results presented above are consistent with the findings obtained by other authors. Similar to the case of the River Gwda catchment, it was concluded that a greater impact was made by precipitation of the previous year than that of the current year (Dobek, 2007; Kowalczyk et al., 2015).

In lowland areas, the climate factor plays a decisive role in the course of the infiltration process, as well as where the level, distribution, frequency and type of precipitation, which are strictly connected with it (Wąsik, 2003), are concerned. This is decisive for the rhythm of groundwater table fluctuations.

A comparison of all these years in which meteorological droughts occurred (Kubiak-Wójcicka \& Bąk, 2018) shows that low groundwater levels were frequently preceded by, or at least overlapped with, years during which meteorological droughts occurred that covered a greater part of the country's area (meteorological droughts occurred in 1983-1985, 1989-1993, 2006 and 2015). In turn, wet years, during which annual precipitation totals considerably exceeded average multi-annual values, occurred in 1981, 1997-2003 and 2010-2011 (Bąk \& Kubiak-Wójcicka, 2017).

The relative similarity of climatic conditions in the area of lowland Poland contributes to the fact that analogous dry periods (2003-2006 and 20112012), as well as wet periods (2000-2002 and 2010), have been distinguished in research work concerning the minimum monthly groundwater status in observation wells located in the Wkra and Skrwa Prawa catchment areas (Kowalczyk et al., 2015).

In areas where the thickness of the unsaturated zone is relatively limited, the groundwater table is vulnerable to temporary changes of hydrometeoro-

Table 5. Correlation coefficient values between precipitation in a given year and groundwater status in a given $(\mathrm{r})$ and the following year $(r+1, r+2)$ for selected piezometers

\begin{tabular}{|c|c|c|c|c|c|c|}
\hline Well number & Depth of well (m) & Water table depth (m) & Type of water table & $\begin{array}{c}\text { Correlation } \\
r\end{array}$ & $\begin{array}{c}\text { Correlation } \\
r+1\end{array}$ & $\begin{array}{c}\text { Correlation } \\
r+2\end{array}$ \\
\hline $\mathrm{I} / 33 / 2$ & 42.0 & 1.2 & perched & 0.20 & 0.50 & -0.10 \\
\hline II/268/1 & 48.5 & 3.7 & perched & -0.12 & 0.40 & 0.14 \\
\hline II/401/1 & 30.0 & 13.0 & free & -0.03 & 0.04 & -0.05 \\
\hline II $/ 417 / 1$ & 24.0 & 0.8 & free & 0.07 & 0.60 & -0.02 \\
\hline
\end{tabular}


logical conditions, which leads to rapid water infiltration into the saturation zone. Moreover, human activity also exerts considerable impact, which is particularly significant on wetlands and swampy terrains (Chlost \& Cieśliński, 2018).

Many authors have emphasised that the issue of groundwater table dynamics is a difficult on account of a number of overlapping factors. The reaction of the catchment to the level and distribution of precipitation requires an individual approach for the research area, which results from variable physical and geographical conditions of the River Gwda catchment area.

\section{Conclusions}

The current study is concerned with an assessment of changes in the groundwater table in the River Gwda catchment area in relation to precipitation in the period between 1981 and 2015. The observed changes in the depth of the groundwater table were connected with the course and distribution of precipitation, as well as with precipitation levels in particular years of the above-mentioned time period.

Our analysis allows the following conclusions to be drawn:

1. On the basis of average annual precipitation totals recorded at meteorological stations located within the River Gwda catchment area in the period between 1981 and 2015, four wet years (1998, 2007, 2010 and 2012) and six dry years (1982, 1989, 1992, 2003 and 2015) have been identified. The remaining years, in which annual precipitation totals corresponded to the average multi-annual values in the period between 1981-2015, have been considered normal.

2. Groundwater status reached higher levels than average multi-annual values recorded in the following years: 1981-1983, 1986, 1988, 1999, 2011 and 2013. Groundwater status lower than the average multi-annual value occurred in 2001 and 2004-2006.

3. The greatest groundwater status fluctuations occurred in observation well II/532/1, where the multi-annual amplitude amounted to $3.99 \mathrm{~m}$, whereas the average annual amplitude reached $1.16 \mathrm{~m}$. The slightest fluctuations occurred in the Quaternary borehole number I/33/2, as well as in the Neogene observation well I/33/2 and reached merely $0.27 \mathrm{~m}$ in average annual amplitude and $0.8 \mathrm{~m}$ in multiannual amplitude.

4. The correlation coefficient $r$, defined in terms of the dependence between precipitation levels and the depth of the groundwater table, has re- vealed that in the majority of cases the reaction of the groundwater table was delayed by at least one year in relation to precipitation.

5. Exceptionally low annual precipitation totals in 2003 in the entire area of the River Gwda catchment and average precipitation totals in 2004 and 2005 resulted in low groundwater status in subsequent years between 2004 and 2009.

6. Low precipitation totals occurring in the southern part of the catchment are not discernible in the groundwater table fluctuations within the multi-annual period under study. This is connected with the location of the observation well in the drainage zone and water ascension from deeper aquifers.

The present study constitutes an introduction to further considerations connected with the influence of other meteorological elements on groundwater table fluctuations, hydrological drought occurrences as well as data development for model tests.

\section{References}

APHP, 2005. Atlas podziatu hydrograficznego Polski [Atlas of Poland's Hydrographic Division], IMGW, Warszawa.

Bartczak, E., 2009. Szczegótowa mapa geologiczna Polski w skali 1:50 000, arkusz Krajenka [Detailed Geological Map of Poland 1:50 000, Krajenka sheet]. PIG-PIB, Warszawa.

Bartnik, A. \& Tomalski, P., 2012. Zróżnicowanie równowagi hydrodynamicznej wód podziemnych i powierzchniowych $w$ dolinie małej rzeki miejskiej (na przykładzie Sokołówki - Łódź) [Spatial diversity of the hydrodynamics equilibrium of groundwater and surface water in small urban river valley (Sokolovka case study - Łodz)]. Monografie Komisji Hydrologicznej PTG 1, 7-19.

Bąk, B. \& Kubiak-Wójcicka, K., 2017. Impact of meteorological drought on hydrological drought in Torun (central Poland) in the period of 1971-2015. Journal of Water and Land Development 32, 3-12.

Chełmicki, W., 1991. Reżim płytkich wód podziemnych $w$ Polsce [A regime of shallow groundwater in Poland]. Uniwersytet Jagielloński, Kraków, 136 pp.

Chlost, I. \& Cieśliński, R., 2018. Effects of environmental and anthropogenic determinants on changes in groundwater levels in selected peat bogs of Slowinski National Park, northern Poland. Geologos 24, 13-28.

Dąbrowski, S., Rynarzewski, W., Straburzyńska-Janiszewska, R. \& Zachaś-Janecka, J., 2013. Odnawialność wód podziemnych zlewni Gwdy [Groundwater reneval of Gwda catchment]. Biuletyn Państwowego Instytutu Geologicznego 456, 97-104.

Dobek, M., 2007. Reakcja zwierciadła wód podziemnych na opad atmosferyczny w latach 1961-1981 w wybranych punktach Wyżyny Lubelskiej [The reaction of groundwater levels to the rainfall in the years 19611981 in selected areas of the Lublin Upland]. Annales 
Universitatis Mariae Curie-Skłodowska. Sectio E. Agricultura $62,49-55$.

Dobracka, E., 2005. Szczegótowa mapa geologiczna Polski, arkusz Połczyn Zdrój (158) wraz z objaśnieniami [Detailed Geological Map of Poland 1:50 000, Połczyn Zdrój sheet with explanations]. PIG, Warszawa.

Graf, R., 2008. Warunki formowania lokalnych systemów krążenia wód podziemnych na obszarze Międzyrzecza Warty i Noteci [Local groundwater-circulation systems in the Warta-Noteć Interfluve (NW Poland)]. Geologos 14, 197-210.

Grajewski, S., Miler, A.T. \& Okoński, B., 2014. Seasonal variability of ground water levels in the Puszcza Zielonka Forest. Journal of Water and Land Development $21,55-62$.

Hołownia, B. \& Wierzbicka, B., 1996. Wskaźnik oceny sytuacji hydrologicznej wód gruntowych [Indicator of the assessment of the hydrological situation of groundwater]. Wiadomości IMGW 19, 40,1.

Jamorska, 2015. Warunki występowania wód podziemnych południowych Kujaw [Hydrogeological conditions of southern Kujawy region]. Przeglad Geologiczny 63, 756-761.

Jędruszkiewicz, J., Zieliński, M. \& Moniewski, P., 2016. Wpływ opadów na wahania zwierciadło wód gruntowych w zachodniej części Wzniesień Łódzkich [The influence of precipitation on water table fluctuation in the western part of Łódź Hills]. Acta Geographica Lodziensia 104, 223-235.

Jokiel, P. \& Moniewski, P., 2000. Warunki gromadzenia i drenażu oraz kierunki ochrony zasobów wód podziemnych w strefie podmiejskiej Łodzi na przykładzie zlewni rzeki Dzierżąznej [Hydrogeological conditions and groundwater protection in the Dzierżązna drainage basin]. Acta Universitatis Lodziensis. Folia Geographica Physica 5, 29-48.

Kondracki, J., 2000. Geografia regionalna Polski [Regional geography of Poland]. PWN, Warszawa, 440 pp.

Kotowski, T. \& Najman, J., 2015. Zastosowanie metody helowej do datowania i rozpoznania warunków krążenia wód podziemnych w zlewni Gwdy [Application of the helium method to dating and recognition of the groundwater circulation within the Gwda River catchment area]. Przegląd Geologiczny 63, 840-845.

Kowalczyk, A., Stępińska-Drygała, I. \& Wesołowski, P. 2015. Zmienność wieloletnia i sezonowa występowania minimalnych stanów wód podziemnych na wybranym obszarze nizinnym [Seasonal and long-term variability of monthly minimum groundwater levels in selected lowland area]. Przegląd Geologiczny 63, 860-866.

Krawiec, A., Pomianowska, H. \& Wijura, A., 2005. Systemy krążenia wód podziemnych w rejonie dolnej Gwdy [Groundwater circulation systems in the lower Gwda valley region]. [In:] A. Sadurski \& A. Krawiec (Eds): Wspótczesne Problemy Hydrogeologii XII [Contemporary Problems of Hydrogeology XII]. Uniwersytet Mikołaja Kopernika, Torun, 383-389.

Kubiak-Wójcicka, K., 2019. Long-term variability of runoff of Vistula river in 1951-2015. [In:] G. Șerban, A. Croitoru, T. Tudose, C. Horváth, R. Bătinaş \&
I. Holobâcă (Eds): Air and Water - Components of the Environment. Babeş-Bolyai University, Cluj-Napoca, 109-120.

Kubiak-Wójcicka, K. \& Bąk, B., 2018. Monitoring of meteorological and hydrological droughts in the Vistula basin (Poland). Environmental and Monitoring Assessment 190, 691.

Kubiak-Wójcicka, K. \& Kornaś, M., 2015. Impact of hydrotechnical structures on hydrological regime of the Gwda and Drawa rivers. Quaestiones Geographicae 34, 99-110.

Kubiak-Wójcicka, K. \& Lewandowska, I., 2014. Changes in the surface area of lakes in the Gwda River basin. Limnological Review 3, 121-129.

Kundzewicz, Z.W. \& Robson, A.J. 2004. Change detection in hydrological records-a review of the methodology. Hydrological Sciences Journal 49, 7-19.

Mojski, J.E., 2005. Ziemie Polski w czwartorzędzie. Zarys morfogenezy [The territory of Poland in the Quaternary. Outline of morphogenesis]. PIG, Warszawa, 404 pp.

Mostowik, K., Kisiel, M., Rzonca, B. \& Siwek, J., 2018. Potencjał zasobności zbiorników wód podziemnych w Bieszczadach Wysokich [The storage capacity of groundwater reservoirs in the High Bieszczady Mountains (SE Poland)]. Przegląd Geograficzny 90, 93-110.

Popielski, W., 2005. Szczegótowa mapa geologiczna Polski, arkusz Barwice (0159) wraz z objaśnieniami [Detailed Geological Map of Poland 1:50 000, Barwice sheet with explanations]. PIG, Warszawa.

Przbyłek, J. \& Nowak, B., 2011. Wpływ niżówek hydrogeologicznych i odwodnień górniczych na systemy wodonośne Pojezierza Gnieźnieńskiego [Impact of hydrogeological low flows and groundwater drainage by lignite open cast mine on aquifer systems of Gniezno Lakeland]. Biuletyn Państwowego Instytutu Geologicznego 445, 127-138.

Szymanko, J., 1980. Koncepcje systemu wodonośnego i metod jego modelowania [Concepts of the water-bearing system and methods of its modeling]. Wydawnictwa Geologiczne, Warszawa, 263 pp.

Tomalski, P., 2011. Dynamika zasobów płytkich wód podziemnych w województwie łódzkim i na obszarach sąsiednich [The dynamics of shallow groundwater resources in the region and neighbouring areas]. Acta Geographica Lodziensia 97, 1-102.

Toth, J., 1963. A theoretical analysis a groundwater flow in small drainage basin. Journal of Geophysical Research 68, 4795-4812.

Wąsik, M., 2003. Zdolność infiltracyjna utworów przypowierzchniowych a zasilanie wód podziemnych [Infiltration capacity of near-surface formations and groundwater recharging]. Acta Universitatis Wratislaviensis 2591, Hydrogeologia. Uniwersytet Wrocławski, Wrocław, 92 pp.

Worsa-Kozak, M., Kotowski, A. \& Wartalski, A., 2008. Monitoring stanów wód podziemnych w rejonie śródmiejskiego węzła wodnego we Wrocławiu [Monitoring of groundwater table levels in the neighborhood of Midtown Water Node in Wrocław City]. Przeglad Geologiczny 56, 302-307. 
Zdralewicz, I. \& Lejcuś, I., 2008. Wyznaczenie okresów niżówkowych wód podziemnych w zlewni górnej Nysy Kłodzkiej [Designation of low groundwater flow periods within upper Nysa Klodzka catchment]. Infrastruktura i Ekologia Terenów Wiejskich 9, 149-158.
Manuscript received: 20 May 2019

Revision accepted: 29 July 2019 